\title{
BUILDING DESIGN INFLUENCE ON THE ENERGY PERFORMANCE
}

\author{
$\operatorname{Ligia}_{\operatorname{Moga}}{ }^{\text {a, }}$, I. Moga ${ }^{a}$ \\ ${ }^{a}$ Technical University of Cluj-Napoca, Faculty of Civil Engineering, Buildings and Management Department, 25 Baritiu Str., \\ Romania, e-mail: ligia.moga@ccm.utcluj.ro
}

Received: 15.03.2015 / Accepted: 01.04.2015 / Revised: 29.04.2015 / Available online: 31.05.2015

DOI: 10.1515/jaes-2015-0005

KEY WORDS: Building Design, Simulation, Energy Performance, Energy Consumption

\begin{abstract}
:
Energy efficient design is a high priority in the national energy strategy of European countries considering the latest requirements of the European Directive on the Energy Performance of Buildings. The residential sector is responsible for a significant quantity of energy consumptions from the total amount of consumptions on a worldwide level. In residential building most of the energy consumptions are given mainly by heating, domestic hot water and lighting. Retrofitting the existing building stock offers great opportunities for reducing global energy consumptions and greenhouse gas emissions. The first part of the paper will address the need of thermal and energy retrofit of existing buildings. The second part will provide an overview on how various variables can influence the energy performance of a building that is placed in all four climatic zones from Romania. The paper is useful for specialist and designers from the construction field in understanding that buildings behave differently from the energy point of view in different climatic regions, even if the building characteristic remain the same.
\end{abstract}

\section{INTRODUCTION}

\subsection{Generalities}

The economic strategy of sustainable development clearly requires promoting rational use of energy at national level, starting from the completion of objectives and measures necessary for most important sectors of final energy consumption, including that of the households. According to the World Business Council for Sustainable Development, buildings account for up to $40 \%$ of energy use in most countries being responsible of about $36 \%$ from the total $\mathrm{CO}_{2}$ emissions at the European Union level.

In Romania the national profile of final energy consumption distribution is represented by $17.5 \%$ in industry, $68.6 \%$ in economic sectors, and about $31.4 \%$ in buildings (smaller compared to the European Union level of about $41 \%$ ). As it can be observed the buildings sector has a great share in improving energy efficiency and thus reducing the energy consumption and the environmental impact.

In order to identify if a building is energy efficient or not, several indicators are calculated and the established values are then compared to reference ones. Therefore, the energy performance of the real building will be compared to the energy performance of the notional building (i.e. reference building). The parameters that make up the notional building are provided in the C107: 2005 and C107: 2010 Romanian Standard for the termotechnical calculation of the construction components of buildings and, which are freely available.

The energy consumed in buildings is influenced not only by temperature, space ventilation and climatic conditions but also by the constructive details and building use. Thus, energy efficiency of buildings is enhanced by the following factors (based on C107 Norm):

- thermal insulation of building components: therefore the heat losses will be reduced;

- shape and building orientation: the building envelope has a great influence on the heat losses and heat gains;

- thermal inertia (mass): represents the thermal property of a material to maintain interior comfort temperature without heating or cooling the space. It reflects the capacity of the building envelope and components to absorb and delay

\footnotetext{
* Corresponding author.
} 
variations of exterior temperature and heat flows generated by solar radiation and by interior heat gains;

- ventilation: includes refreshing the interior air with fresh air and also ensuring comfort during summer time. Air conditioning is mainly oriented towards controlled natural ventilation due to energy savings requirements and drawbacks related to mechanical ventilation;

- harnessing solar energy: nowadays a range of ever-evolving technologies can be used such as solar photovoltaics, solar thermal energy, solar heating and others;

- daylight harnessing: energy reduction can be obtained through improved strategies for good daylight design like shape and dimensions of glazing surfaces, avoiding window obstructions by trees, colouring opposite surfaces of the windows in light nuances and others.

The energy performance of buildings is the effective or estimated energy consumed in order to meet the needs related to the normal use of the buildings. The energy consumptions are given by space heating, domestic hot water consumption, space cooling, space ventilation and lighting.

The energy performance of buildings is given by a national calculation methodology described in Mc0001 and is expressed by several numerical indicators that are calculated based on the thermal insulation, technical characteristics of the building envelope and building services, design and location of the building in relation to exterior climatic factors, sunlight exposure and influence of surrounding buildings, own sources of energy production and other factors like interior environment, factor that also has a significant influence on the energetic performance of the building.

The next indicators are expressing the energetic behaviour of the building:

- the energy class (see figure 1): is established based on the values obtained through calculations for several consumptions and the overall consumption of the building;

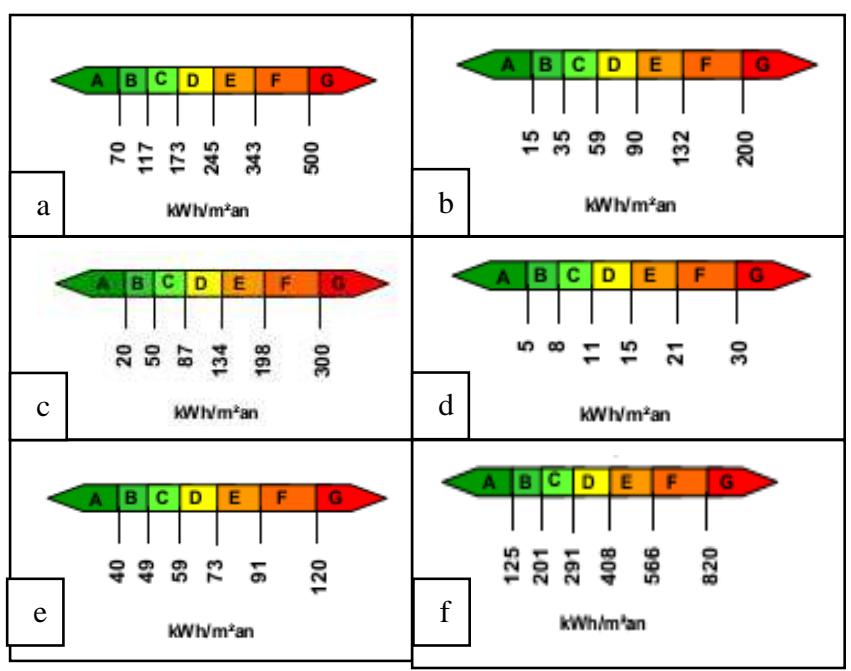

Figure 1. Energy consumption class (a) heating, (b) hot water consumption, (c) cooling, (d) mechanical ventilation, (e) lighting, (f) total energy consumption
- the total energy consumption of the building: based on the calculation made on the building envelope the annual heat demand can be established in $\mathrm{kWh} /$ year. By dividing the annual heat demand to the useful surface of the building the heating index required for heating will be obtained in $\mathrm{kWh} / \mathrm{m}^{2}$ year. The total energy consumption in $\mathrm{kWh} / \mathrm{m}^{2}$ year will be established based on the energy consumptions of the building utilities;

- the $\mathrm{CO}_{2}$ equivalent emission index: knowing the specific energy demand of the building and the type of fuel used, using the conversion factor, the primary energy demand by fuel type can be calculated. With the energy demand value and $\mathrm{CO}_{2}$ emission index de annual $\mathrm{CO}_{2}$ emission can be established.

\subsection{Thermal retrofit of buildings}

The thermal modernization process of a building is given by the measures implemented for an existing building in order to improve thermal insulation and the airtightness of the building envelope, thus reducing the heat losses and ensuring the minimum comfort and hygienic conditions, including avoidance of superficial and interstitial condensation risk. A second consequence of optimizing the thermal performance of the building will consist in reduction of the energy consumptions and hence the pollutant emissions throughout the lifecycle of the building at a level set by the European and national legislation,

The thermal rehabilitation (retrofit) of buildings has a dual effect on the hydrothermal behaviour of the building:

- in the cold season of the year when the heat losses through building components are usually bigger, after the thermal rehabilitation process a significant reduction of the heat losses is achieved and hence of the energy consumption of the building,;

- in the hot season of the year there is a great need in reducing the energy used at cooling the interior spaces. This energy demand is reduced both by placing thermal insulation systems on the exterior surface of the building components and by placing shading devices at glazing surfaces.

The interventions are made both on the building envelope and on the building services. The final aim of the retrofitting process is to bring as close as possible the energy performance of the building to initial design phase values.

\section{CALCULATION METHODOLOGY}

\subsection{Global thermal insulation coefficient}

In order to establish the thermal behaviour of the building envelope the global thermal insulation coefficient $G$ must be established. The $\mathrm{G}$ coefficient represents the amount of heat losses by heat transfer through the building envelope components without taking into account the solar heat and interior heat gains. The calculation methodology of $\mathrm{G}\left(\mathrm{W} / \mathrm{m}^{3} \mathrm{~K}\right)$ is given in $\mathrm{C} 107$ volume 1 for residential buildings and C107 volume 2 for other types of buildings. 
For residential buildings the following formula is applied:

$$
G=\frac{\sum L_{m j} \cdot \tau_{j}}{V}+0.34 \cdot n
$$

where: $\mathrm{L}_{\mathrm{mj}}$ is the thermal coupling coefficient of the construction element type ,m” (W/K), established by applying:

$$
L_{m j}=\frac{A_{m j}}{R_{m j}^{\prime}}
$$

where: $\mathrm{R}_{\mathrm{mj}}$ is the medium adjusted thermal resistance of the element type ,m” $\left(\mathrm{m}^{2} \mathrm{~K} / \mathrm{W}\right)$, $\left(\mathrm{m}^{2}\right)$,

$A_{m j}$ is the area of the construction element type „m”

$\mathrm{V}$ is the interior heated volume of the building $\left(\mathrm{m}^{3}\right)$,

$\tau_{\mathrm{j}}$ is the temperature correction coefficient (-) calculated as it follows:

$$
\tau_{j}=\frac{T^{\prime}{ }_{i}-T_{j}}{T_{i}-T_{e}}
$$

where: $T_{i}$ is the calculation temperature of the interior environment of the building, for residential buildings a design value of $+20^{\circ} \mathrm{C}$ is recommended,

$\mathrm{T}_{\mathrm{e}}$ is the calculation temperature of the exterior environment based on the climatic zones existing in Romania: $\mathrm{I}^{\mathrm{st}} \mathrm{T}_{\mathrm{e}}=-12^{\circ} \mathrm{C}$, II $^{\text {nd }} \mathrm{T}_{\mathrm{e}}=-15^{\circ} \mathrm{C}, \mathrm{III}^{\text {rd }} \mathrm{T}_{\mathrm{e}}=-18^{\circ} \mathrm{C}, \mathrm{IV}^{\text {th }} \mathrm{T}_{\mathrm{e}}=-21^{\circ} \mathrm{C}$,

$T_{j}$ is the temperature of the unheated space, other interior $T_{j}=T_{u}$ or exterior environment $T_{j}=T_{e}$,

$\mathrm{T}{ }_{\mathrm{i}}$ is the temperature of the interior space next to the construction element,

$\mathrm{n}$ is the natural ventilation speed of the building (the ventilation rate) given by the air exchanges per hour in a space $(1 / \mathrm{h})$.

The $\mathrm{G}$ value obtained for a given building must be compared to a reference values given by C107:2010, using the following:

$$
\mathrm{G} \leq \mathrm{GN}
$$

where: GN is the reference global thermal coefficient $\left(\mathrm{W} / \mathrm{m}^{3} \mathrm{~K}\right)$, established based on the number of levels of the building and the ratio between the area of the building envelope $\mathrm{A}$ and the heated volume of the building $\mathrm{V}$.

\subsection{Annual heat demand calculation based on $\mathrm{C107}$ norm}

The annual heat demand $\mathrm{Q}\left(\mathrm{kWh} / \mathrm{m}^{3 \cdot}\right.$ year $)$ is calculated with the following formula given in $\mathrm{C} 107$ norm:

$$
Q=\frac{24}{1000} \cdot C \cdot N_{12}^{\theta_{i}} \cdot G-\left(Q_{i}+Q_{s}\right)
$$

where: $\mathrm{C}$ is the correction coefficient (-),

$\mathrm{N}^{\theta \mathrm{i}}{ }_{12}$ the annual heating degree days (K'days),

$\mathrm{Q}_{\mathrm{i}}$ interior heat gains $\left(\mathrm{kWh} / \mathrm{m}^{3}\right.$ year),

$\mathrm{Q}_{\mathrm{s}}$ solar heat gains $\left(\mathrm{kWh} / \mathrm{m}^{3 \cdot}\right.$ year $)$.
The obtained value of $\mathrm{Q}$ must be compared with a reference value given by $\mathrm{QN}\left(\mathrm{kWh} / \mathrm{m}^{3 \cdot}\right.$ year) given in $\mathrm{C} 107$ Norm- book 1:

$$
\mathrm{Q} \leq \mathrm{QN}
$$

\subsection{Annual energy demand for heating calculated based on Mc001 methodology}

In order to establish the heating energy class of the building a simplification methodology was established for calculating the heating index required for heating. Several heat quantities will be calculated: heat quantity necessary for heating lost through the building envelope components $Q_{\text {heat }}$, heat quantity necessary for heating lost through ventilation $\mathrm{Q}_{\text {vent }}$, interior heat gains $\mathrm{Q}_{\mathrm{i}}$, solar heat gains $\mathrm{Q}_{\mathrm{s}}$. The efficiency of the heating system will be also considered in calculations and the heat quantity at the source will therefore be established $\mathrm{Q}_{\text {heat.vent.source. The quantities }}$ established will be in ( $\mathrm{kWh} /$ year). In order to identify the heating index $\mathrm{q}_{\text {heat }}\left(\mathrm{kWh} / \mathrm{m}^{2}\right.$ year $)$ the following will be applied:

$$
q_{\text {inc }}=\frac{Q_{\text {heat.vent.source }}}{A_{\text {useful }}}-\frac{Q_{i}+Q_{s}}{A_{\text {useful }}}
$$

where: $A_{\text {useful }}$ is the useful area of the building $\left(\mathrm{m}^{2}\right)$.

\section{CASE STUDY}

\subsection{The case study approach}

The paper analysed the energy performance of an existing building in comparison with other solutions for the building, with a focus on the influence of the climatic zone where the building is located and on the number of the building levels (i.e. height regime of the building).

In order to establish the proper thermal rehabilitation solutions for the existing building the calculations were first made on the existing building and the reference building. Afterwards two thermal rehabilitation solutions were proposed with the aim of increasing the energy performance of the building.

For the second part of the study the building was considered in the first thermal rehabilitation solution. Several height regimes and locations in the 4 climatic zones were considered in order to analyse the energy performance of the described cases.

Thus 20 variants were analysed:

$\mathrm{I}^{\text {st }}$ climatic zone: $\mathrm{GF}+2 \mathrm{~F}, \mathrm{GF}+4 \mathrm{~F}, \mathrm{GF}+5 \mathrm{~F}, \mathrm{GF}+6 \mathrm{~F}, \mathrm{GF}+10 \mathrm{~F}$ II $^{\text {nd }}$ climatic zone: $G F+2 F, G F+4 F, G F+5 F, G F+6 F, G F+10 F$ III ${ }^{\text {rd }}$ climatic zone: $\mathrm{GF}+2 \mathrm{~F}, \mathrm{GF}+4 \mathrm{~F}, \mathrm{GF}+5 \mathrm{~F}, \mathrm{GF}+6 \mathrm{~F}, \mathrm{GF}+10 \mathrm{~F}$ IV $^{\text {th }}$ climatic zone: $G F+2 F, G F+4 F, G F+5 F, G F+6 F, G F+10 F$

First the geometric characteristics of the building envelope were identified, area of the building envelope, area of the building components and the heated volume. The second step was the calculation of the adjusted thermal resistances $R^{\prime}$ for each construction element, of the thermal coupling coefficient $\mathrm{L}$ and of the global thermal insulation coefficient G. The annual heat demand and the annual energy demand for heating were calculated in order to obtain the energy class for heating. $q_{\text {heat }}$. 


\subsection{Building description}

The evaluated building is a block of flats from Cluj-Napoca, with the height regime of GF+4F. Cluj-Napoca is in the III ${ }^{\text {rd }}$ climatic zone with an exterior temperature of $\mathrm{T}_{\mathrm{e}}=-18^{\circ} \mathrm{C}$ based on $\mathrm{C} 107$. The interior predominant temperature was considered $\mathrm{T}_{\mathrm{i}}=20^{\circ} \mathrm{C}$, and for the basement a temperature of $\mathrm{T}_{\mathrm{u}}=5^{\circ} \mathrm{C}$ was considered.

The height of one level is $2.8 \mathrm{~m}$ and the useful height is $2.62 \mathrm{~m}$. Total built area is $279.6 \mathrm{~m}^{2}$. The main entrance in the building is on the North facade. The structure is masonry with reinforced concrete pillars of $25 \times 25 \mathrm{~cm}$. The building envelope is represented by:

- the area of the vertical envelope is given by 18 wall panels at the GF level with a height of $2.69 \mathrm{~m}, 18$ wall panels at the intermediate floors with a height of $2.8 \mathrm{~m}$, and 18 wall panels at the last heated level with a height of $2.725 \mathrm{~m}$. The total area of the vertical envelope is $997.473 \mathrm{~m}^{2}$, from which $133.77 \mathrm{~m}^{2}$ is the glazed surface and $863.703 \mathrm{~m}^{2}$ is the opaque one;

- the area of the horizontal envelope is $515.16 \mathrm{~m}^{2}$, given by the floor over the unheated basement of $257.58 \mathrm{~m}^{2}$ and the terrace floor of $257.58 \mathrm{~m}^{2}$

The interior heated volume of the building envelope is $3558.468 \mathrm{~m}^{3}$.

The adjusted thermal resistances for the building envelope components are established by calculating the medium unidirectional thermal resistance in the current field of the element which is afterwards adjusted by considering the influence of the linear and punctual thermal bridges coefficients, i.e. $\psi$ and $\chi$, for each panel.

The exterior wall is represented by ceramic blocks of $30 \mathrm{~cm}$ having a thermal conductivity of $\lambda=0.207 \mathrm{~W} / \mathrm{m} \cdot \mathrm{K}$. The blocks are plastered on both surfaces with cement mortar in a thickness of $1.5 \mathrm{~cm}$ on the exterior surface and $1 \mathrm{~cm}$ on the interior surface. The field thermal resistance is $\mathrm{R}=1.471 \mathrm{~m}^{2} \mathrm{~K} / \mathrm{W}$. An example for the calculation of the adjusted thermal resistance of a wall panel is given below. The linear heat transfer coefficients were chosen based on the constructive details of the wall panel (figures 2, 3).

$$
\begin{aligned}
& U^{\prime}=\frac{1}{R}+\frac{h_{a 1} \cdot \psi_{a 1}+h_{b 1} \cdot \psi_{b 1}+l_{c 1} \cdot \psi_{c 1}+l_{d 1} \cdot \psi_{d 1}+}{h_{b 1} \cdot l_{c 1}-1.2 \cdot 1.2} \\
& \frac{+l_{e 1} \cdot \psi_{e 1}+2 \cdot h_{f 1} \cdot \psi_{f 1}+l_{g 1} \cdot \psi_{g 1}}{h_{b 1} \cdot l_{c 1}-1.2 \cdot 1.2}=0.852 \frac{W}{m^{2} \cdot K} \\
& R^{\prime}=\frac{1}{U}{ }^{\prime}=1.174 \frac{m^{2} \cdot K}{W}
\end{aligned}
$$

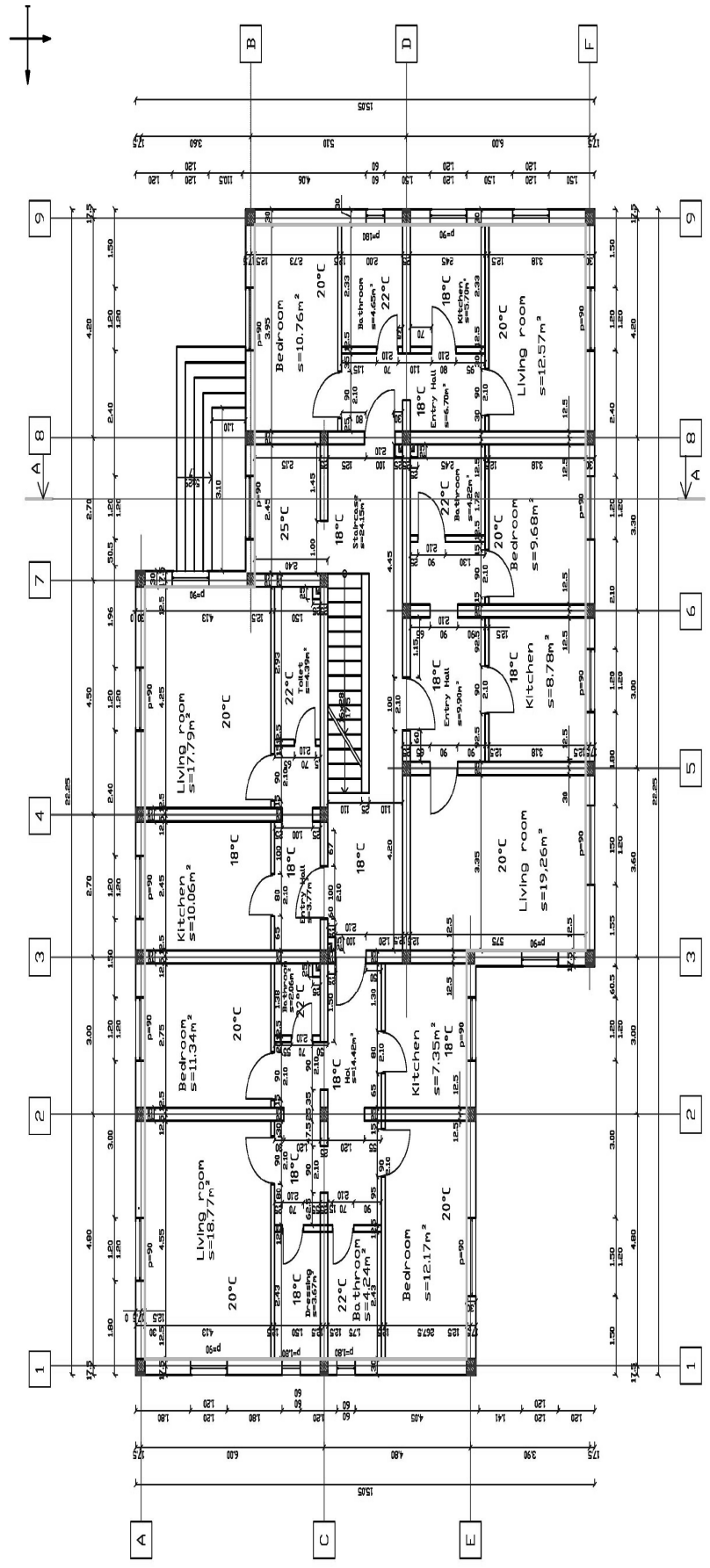

Figure 2. Current floor of the building 


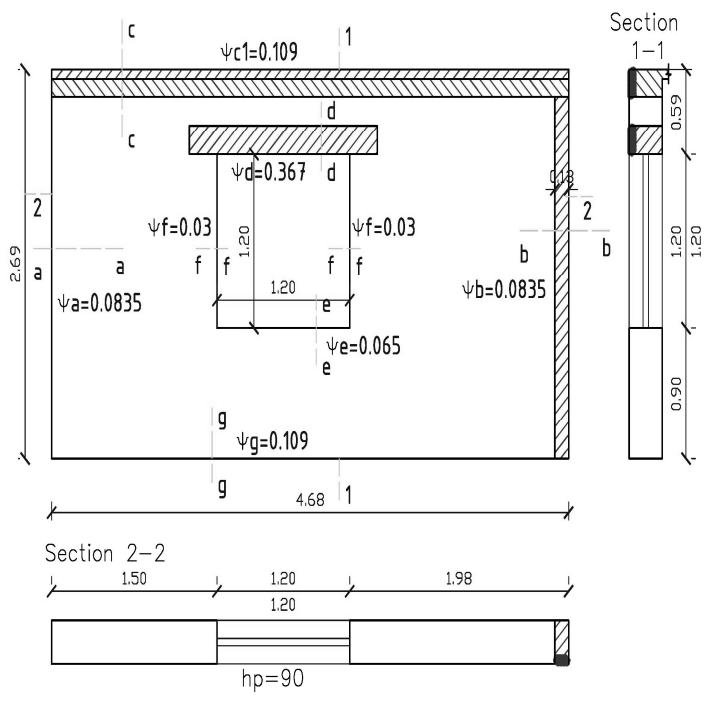

Figure 3. Wall panel with linear heat transfer coefficients

The interior partition walls are made with $25 \mathrm{~cm}$ ceramic blocks. The terrace roof is an uncirculated surface having an adjusted thermal resistance $\mathrm{R}^{\prime}=1.974 \mathrm{~m}^{2} \mathrm{~K} / \mathrm{W}$. The floor over the unheated basement has a medium adjusted thermal resistance $\mathrm{R}^{\prime}=0.396 \mathrm{~m}^{2} \cdot \mathrm{K} / \mathrm{W}$.

Exterior glazing is a double glazing unit with a treated surface $\varepsilon$ $=0.02$ and a wood frame. The building has 3 type of glazing units: $0.60 \mathrm{~m} \times 0.60 \mathrm{~m}, 1.20 \mathrm{~m} \times 1.20 \mathrm{~m}, 1.20 \mathrm{~m} \times 1.50 \mathrm{~m}$. The exterior door is a double glazed wood frame. The adjusted thermal resistances for each type of glazing surface was established, e.g. for the $1.20 \mathrm{~m} \times 1.20 \mathrm{~m} \mathrm{R}^{\prime}=0.533 \mathrm{~m}^{2} \mathrm{~K} / \mathrm{W}$.

After calculating the adjusted thermal resistances for each building envelope component, the results will be summarized in a table based on which the thermal coupling coefficient $\mathrm{L}$ and afterwards the global thermal insulation coefficient $\mathrm{G}$ will be calculated. For the real building the $G$ value obtained was $\mathrm{G}=0.552\left(\mathrm{~W} / \mathrm{m}^{3} \cdot \mathrm{K}\right)$.

The value was compared to the standard one $\mathrm{GN}=0.43$ $\left(\mathrm{W} / \mathrm{m}^{3} \mathrm{~K}\right)$. Because $\mathrm{G}>\mathrm{GN}$ it resulted that the building must by optimized from the energetic point of view, which means that several thermal rehabilitation solutions can be proposed.

The annual heat demand resulted in a value $Q=37.234$ $\left(\mathrm{kWh} / \mathrm{m}^{3}\right.$ year) which was greater than the standard value $\mathrm{QN}=$ $20.625\left(\mathrm{kWh} / \mathrm{m}^{3}\right.$ year$)$. The $\mathrm{Q}$ value was established for a standard heating period for Cluj-Napoca of 218 days.

The heating index was established based on the annual energy demand for heating $\mathrm{q}_{\text {heat }}=205.007\left(\mathrm{kWh} / \mathrm{m}^{2}\right.$ year $)$. The real building is situated in D energy class for heating.

\subsection{The thermal rehabilitation of buildings}

For the thermal rehabilitation two variants were proposed:

- the first variant: $10 \mathrm{~cm}$ of expanded polystyrene for the exterior walls $\mathrm{R}^{\prime}=2.476 \mathrm{~m}^{2} \cdot \mathrm{K} / \mathrm{W}, 5 \mathrm{~cm}$ of expanded polystyrene for the floor over the unheated basement $\mathrm{R}^{\prime}=3.97$ $\mathrm{m}^{2} \cdot \mathrm{K} / \mathrm{W}, 20 \mathrm{~cm}$ of expanded polystyrene for the terrace floor $\mathrm{R}^{\prime}=3.697 \mathrm{~m}^{2} \cdot \mathrm{K} / \mathrm{W}$, glazing surface with a $\mathrm{R}=0.90 \mathrm{~m}^{2} \cdot \mathrm{K} / \mathrm{W}$.

- the second variant: $20 \mathrm{~cm}$ of expanded polystyrene for the exterior walls $\mathrm{R}^{\prime}=3.305 \mathrm{~m}^{2} \mathrm{~K} / \mathrm{W}, 10 \mathrm{~cm}$ of expanded polystyrene for the floor over the unheated basement $\mathrm{R}^{\prime}=6.801 \mathrm{~m}^{2} \cdot \mathrm{K} / \mathrm{W}, 30 \mathrm{~cm}$ of expanded polystyrene for the terrace floor $\mathrm{R}^{\prime}=5.007 \mathrm{~m}^{2} \cdot \mathrm{K} / \mathrm{W}$, glazing surface with $\mathrm{R}=1.102$ $\mathrm{m}^{2} \cdot \mathrm{K} / \mathrm{W}$.

\section{RESULTS}

\subsection{The thermal rehabilitated variants}

For the thermal rehabilitated variants only the $G$ value and the $\mathrm{q}_{\text {heat }}$ were calculated. Thus the following results were obtained:

- the first variant: $\mathrm{G}$ value obtained was $\mathrm{G}=0.415\left(\mathrm{~W} / \mathrm{m}^{3} \mathrm{~K}\right)$. The value was compared to the standard one $\mathrm{GN}=0.43$ $\left(\mathrm{W} / \mathrm{m}^{3} \mathrm{~K}\right)$, and resulted that $\mathrm{G}<\mathrm{GN}$. $\mathrm{q}_{\text {heat }}=85.159$ $\left(\mathrm{kWh} / \mathrm{m}^{2}\right.$ year) which gave a B energy class.

- the second variant: $\mathrm{G}$ value obtained was $\mathrm{G}=0.37\left(\mathrm{~W} / \mathrm{m}^{3} \cdot \mathrm{K}\right)$. The value was compared to the standard one $\mathrm{GN}=0.43$ $\left(\mathrm{W} / \mathrm{m}^{3} \mathrm{~K}\right)$, and resulted that $\mathrm{G}<\mathrm{GN}$. $\mathrm{q}_{\mathrm{heat}}=71.947$ $\left(\mathrm{kWh} / \mathrm{m}^{2}\right.$ year) which gave a B energy class.

A comparison between the heating index for the existing building, reference building and for the 2 thermal insulation variants is presented in figure 4 .

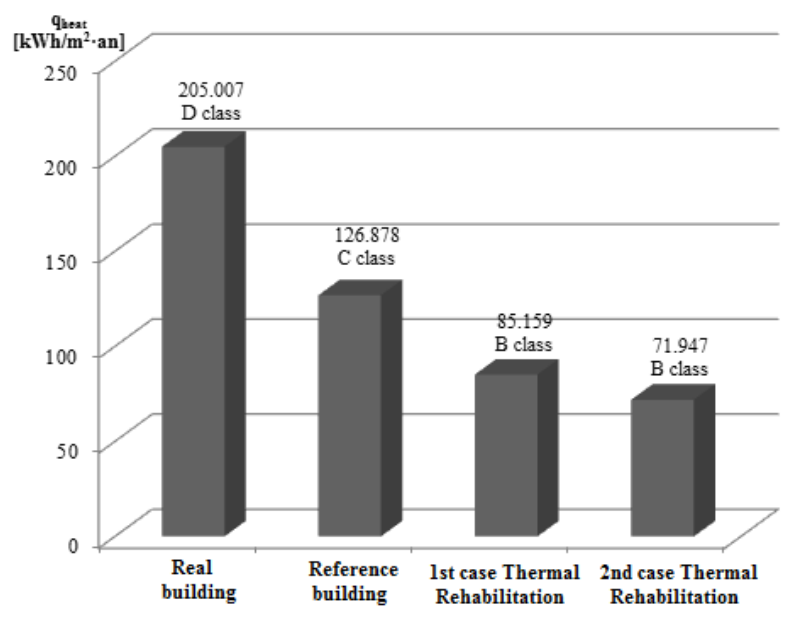

Figure 4. Heating indexes for the studied cases

\subsection{The 20 studied variants}

4.2.1. General calculations: The main differences for the analysed cases are given by the changes of the geometric characteristics for each type of building: the number of the building levels, the area of the building envelope, the glazing area, the number of the wall panels, the useful area of the building and the interior heated volume. The orientation and shape of the building remains the same (tables 1,2). 


\begin{tabular}{|c|c|c|c|}
\hline $\begin{array}{l}\text { Geometric } \\
\text { characteristics }\end{array}$ & $\mathrm{GF}+2 \mathrm{~F}$ & $\mathrm{GF}+4 \mathrm{~F}$ & $\mathrm{GF}+5 \mathrm{~F}$ \\
\hline Level number & 3 & 5 & 6 \\
\hline Building envelope $\left[\mathrm{m}^{2}\right]$ & 1108.67 & 1512.99 & 1715.10 \\
\hline Glazing surface $\left[\mathrm{m}^{2}\right]$ & 79.560 & 132.99 & 158.40 \\
\hline Useful area & 691.98 & 1158.84 & 1392.27 \\
\hline Heated volume $\quad\left[\mathrm{m}^{3}\right]$ & 2116.02 & 3558.47 & 4279.69 \\
\hline
\end{tabular}

\begin{tabular}{|c|c|c|}
\hline Geometric characteristics & $\mathrm{GF}+6 \mathrm{~F}$ & $\mathrm{GF}+10 \mathrm{~F}$ \\
\hline Level number & 7 & 11 \\
\hline Building envelope $\left[\mathrm{m}^{2}\right]$ & 1917.313 & 2725.953 \\
\hline Glazing surface $\quad\left[\mathrm{m}^{2}\right]$ & 184.680 & 289.800 \\
\hline Useful area & 1625.700 & 2559.420 \\
\hline Heated volume $\quad\left[\mathrm{m}^{3}\right]$ & 5000.916 & 7885.812 \\
\hline
\end{tabular}

Table 1. Geometric characteristics of the analysed cases

\begin{tabular}{|c|c|c|c|c|c|}
\hline $\begin{array}{l}\text { Height } \\
\text { regime }\end{array}$ & $\begin{array}{c}\text { Climatic } \\
\text { zone }\end{array}$ & $\begin{array}{c}\mathrm{G} \\
\mathrm{W} / \mathrm{m}^{3} \mathrm{~K} \\
\end{array}$ & $\begin{array}{c}\text { Qheat.vent.source } \\
\mathrm{kWh} / \mathrm{yr}\end{array}$ & $\begin{array}{c}\mathrm{Q}_{\mathrm{i}} \\
\mathrm{kWh} / \mathrm{yr}\end{array}$ & $\begin{array}{c}\mathrm{Q}_{\mathrm{s}} \\
\mathrm{kWh} / \mathrm{yr}\end{array}$ \\
\hline \multirow{4}{*}{$\mathrm{GF}+2 \mathrm{~F}$} & $1^{\text {st }}$ & 0.445 & 59571,98 & 12.36 & 1.35 \\
\hline & $2^{\text {nd }}$ & 0.445 & 47949,15 & 12.95 & 1.22 \\
\hline & $3^{\text {nd }}$ & 0.445 & 80483,95 & 14.48 & 1.26 \\
\hline & $4^{\text {th }}$ & 0.443 & 89586,59 & 16.08 & 1.19 \\
\hline \multirow{4}{*}{$\mathrm{GF}+4 \mathrm{~F}$} & $1^{\mathrm{st}}$ & 0.414 & 94055,71 & 20.69 & 2.25 \\
\hline & $2^{\text {nd }}$ & 0.416 & 105828,40 & 21.69 & 2.03 \\
\hline & $3^{\text {nd }}$ & 0.415 & 129806,21 & 24.25 & 2.11 \\
\hline & $4^{\text {th }}$ & 0.414 & 139713,72 & 26.92 & 1.99 \\
\hline \multirow{4}{*}{$\mathrm{GF}+5 \mathrm{~F}$} & $1^{\mathrm{st}}$ & 0.407 & 109675,35 & 24.86 & 2.69 \\
\hline & $2^{\text {nd }}$ & 0.408 & 124768,02 & 26.06 & 2.44 \\
\hline & $3^{\text {nd }}$ & 0.408 & 147431,23 & 29.14 & 2.53 \\
\hline & $4^{\text {th }}$ & 0.407 & 164815,46 & 32.35 & 2.39 \\
\hline \multirow{4}{*}{$\mathrm{GF}+6 \mathrm{~F}$} & $1^{\mathrm{st}}$ & 0.402 & 126376,47 & 29.03 & 3.13 \\
\hline & $2^{\text {nd }}$ & 0.403 & 154021,25 & 30.43 & 2.83 \\
\hline & $3^{\text {nd }}$ & 0.403 & 169818,18 & 34.02 & 2.32 \\
\hline & $4^{\text {th }}$ & 0.402 & 189917,17 & 37.77 & 2.767 \\
\hline \multirow{4}{*}{$\mathrm{GF}+10 \mathrm{~F}$} & $1^{\mathrm{st}}$ & 0.39 & 213894,60 & 45.7 & 4.92 \\
\hline & $2^{\text {nd }}$ & 0.392 & 242872,00 & 47.91 & 4.44 \\
\hline & $3^{\text {nd }}$ & 0.392 & 259365,60 & 53.56 & 4.61 \\
\hline & $4^{\text {th }}$ & 0.391 & 290324,30 & 59.46 & 4.35 \\
\hline
\end{tabular}

Table 2. Calculation results 
Following the calculation steps presented for the real building the heat demands, the annual energy demands and the heating index were established (table 3 ).

\begin{tabular}{|c|c|c|c|c|c|}
\hline $\begin{array}{c}\text { Height } \\
\text { level }\end{array}$ & GF+2F & GF+4F & GF+5F & GF+6F & GF+10F \\
$\begin{array}{c}\text { matic } \\
\text { zone }\end{array}$ & G & & & \\
\hline $1^{\text {st }}$ & 80.14 & 74.29 & 72.84 & 71.81 & 69.12 \\
\hline $2^{\text {nd }}$ & 92.44 & 85.57 & 83.87 & 82.66 & 80.01 \\
\hline $3^{\text {nd }}$ & 110.18 & 102.09 & 100.08 & 98.66 & 95.54 \\
\hline $4^{\text {th }}$ & 123.74 & 114.85 & 112.67 & 111.12 & 107.74 \\
\hline
\end{tabular}

Table 3. Annual energy demand for heating $\mathrm{q}_{\text {heat }}\left(\mathrm{kWh} / \mathrm{m}^{2}\right.$ year $)$

4.2.2. Building height regime influence on the annual energy demand: The energy class was established based on the heating index (figures 5, 6, 7, 8).

For all the examined cases was observed that the annual heating index decreases with the increase in the building height. An explanation for the obtained results is due to the increased surface of the vertical envelope (i.e. exterior walls) compared to the horizontal one (i.e. terrace roof, floor over unheated basement).

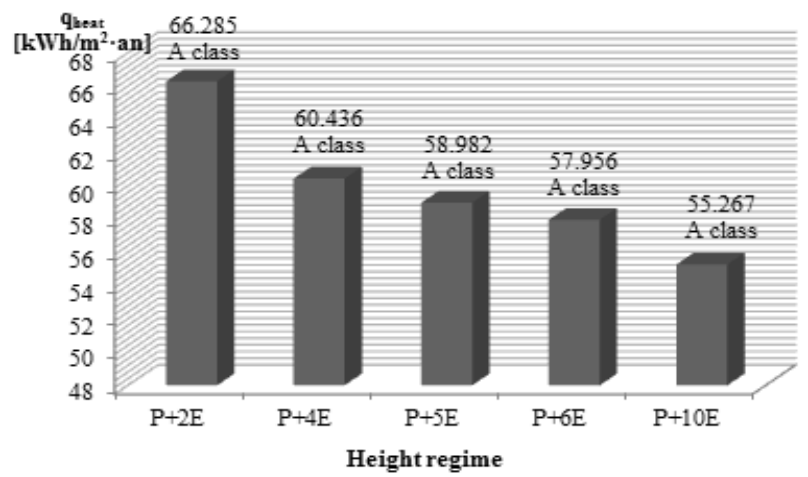

Figure 5. Building located in the $1^{\text {st }}$ climatic zone

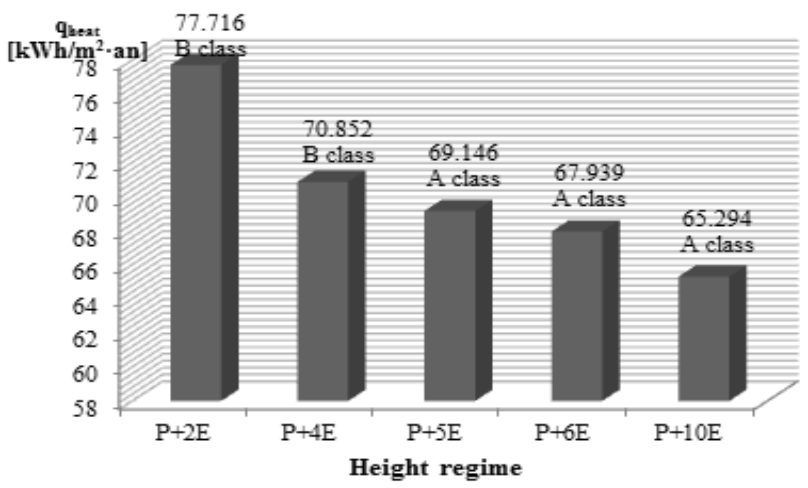

Figure 6. Building located in the $2^{\text {nd }}$ climatic zone

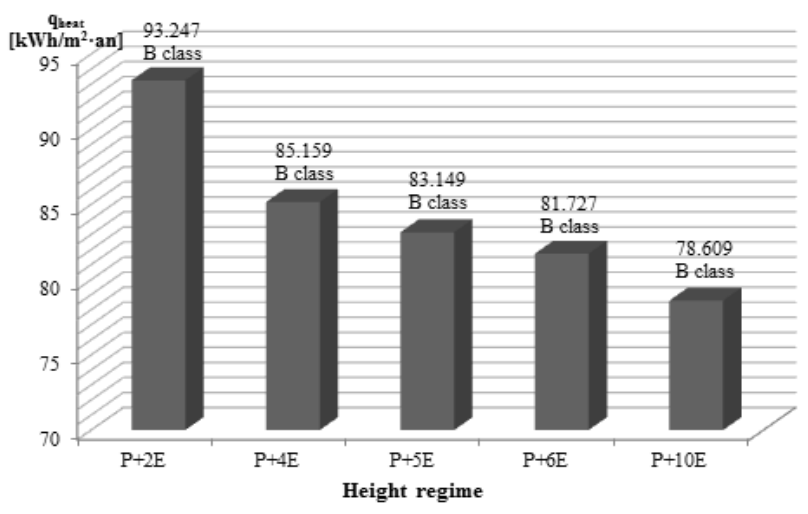

Figure 7. Building located in the $3^{\text {nd }}$ climatic zone

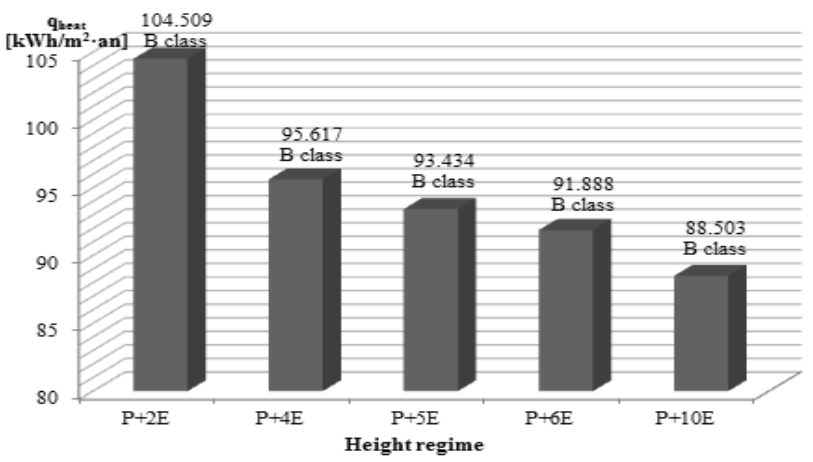

Figure 8 . Building located in the $4^{\text {th }}$ climatic zone

4.2.3. Climatic zone influence on the annual energy demand (figures 9, 10, 11, 12): The climatic zone of the building location influences the energy heat demand due to the different characteristics such as exterior temperature, $D_{12}$ number of heating days during a year, $\theta_{\mathrm{a}}$ annual average exterior temperature, $\theta_{\mathrm{em}}$ average exterior temperature of the heated days and the solar radiation intensity. The values given in table 4 were considered in calculations.

\begin{tabular}{|c|c|c|c|c|}
\hline $\begin{array}{c}\text { Climatic } \\
\text { zone }\end{array}$ & Location & $\begin{array}{c}\theta_{\mathrm{a}} \\
{ }^{\circ} \mathrm{C}\end{array}$ & $\begin{array}{c}\mathrm{N}_{12}{ }^{20} \\
\mathrm{~K} \cdot \mathrm{days}\end{array}$ & $\begin{array}{c}\mathrm{D}_{12} \\
\text { days }\end{array}$ \\
\hline $1^{\text {st }}$ & Constanța & 11.5 & 2840 & 186 \\
\hline $2^{\text {nd }}$ & Oradea & 10.2 & 3150 & 195 \\
\hline $3^{\text {nd }}$ & Cluj-Napoca & 8.3 & 3730 & 218 \\
\hline $4^{\text {th }}$ & $\begin{array}{c}\text { Miercurea- } \\
\text { Ciuc }\end{array}$ & 6.5 & 4250 & 242 \\
\hline $\begin{array}{c}\text { Climatic } \\
\text { zone }\end{array}$ & $\begin{array}{c}\text { Location } \\
1^{\text {st }}\end{array}$ & $\begin{array}{c}\theta_{\mathrm{em}} \\
{ }^{\circ} \mathrm{C}\end{array}$ & $\begin{array}{c}\mathrm{T}_{\mathrm{e}} \\
{ }^{\circ} \mathrm{C}\end{array}$ & $\begin{array}{c}\mathrm{T}_{\mathrm{u}} \\
{ }^{\circ} \mathrm{C}\end{array}$ \\
\hline $2^{\text {nd }}$ & Oradea & 3.874 & -15 & 8 \\
\hline $3^{\text {nd }}$ & Cluj-Napoca & 2.981 & -18 & 5 \\
\hline $4^{\text {th }}$ & $\begin{array}{c}\text { Miercurea- } \\
\text { Ciuc }\end{array}$ & 2.815 & -21 & 5 \\
\hline
\end{tabular}

Table 4. Climatic conditions for the four climatic zones where $T_{u}$ is the temperature of the unheated basement 


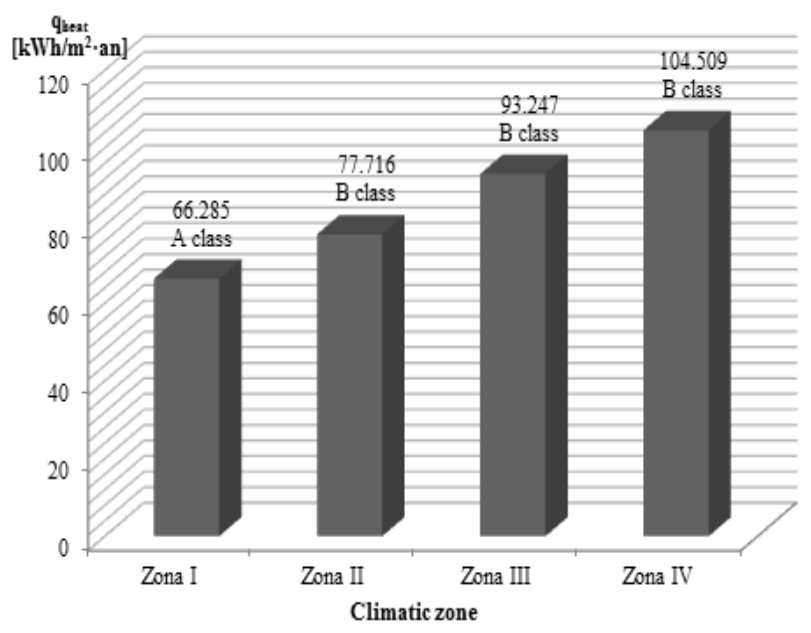

Figure 9. Heating index for the $\mathrm{GF}+2 \mathrm{~F}$ building

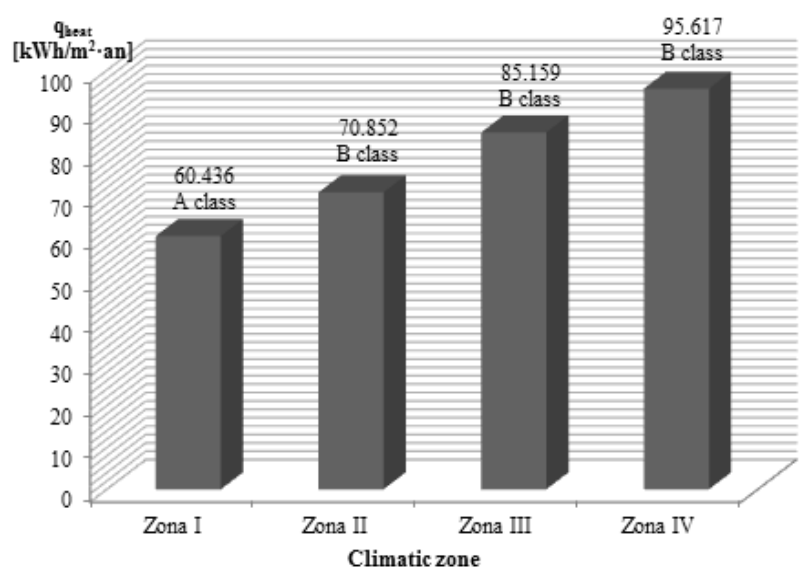

Figure 10. Heating index for the GF+4F building

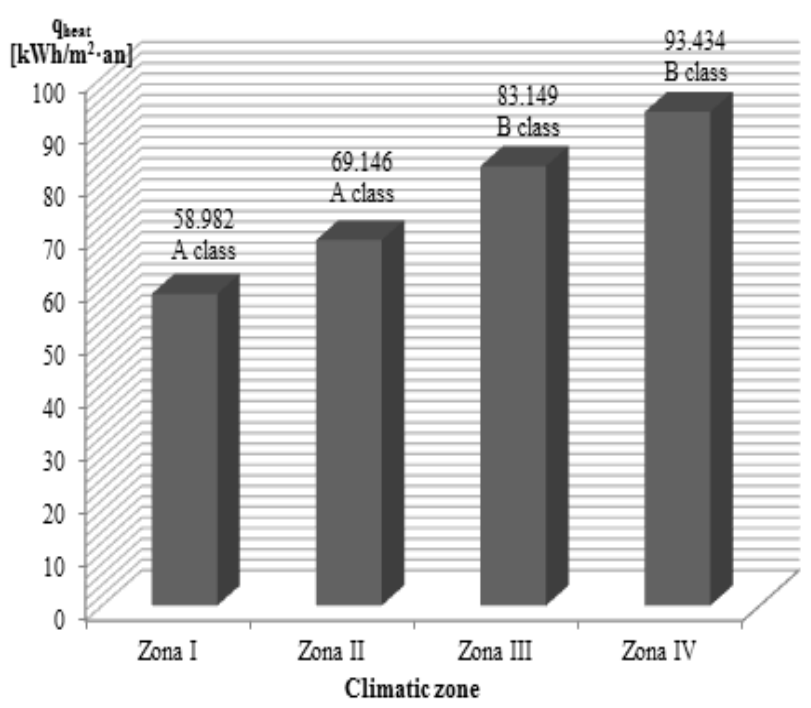

Figure 11. Heating index for the GF+5F building

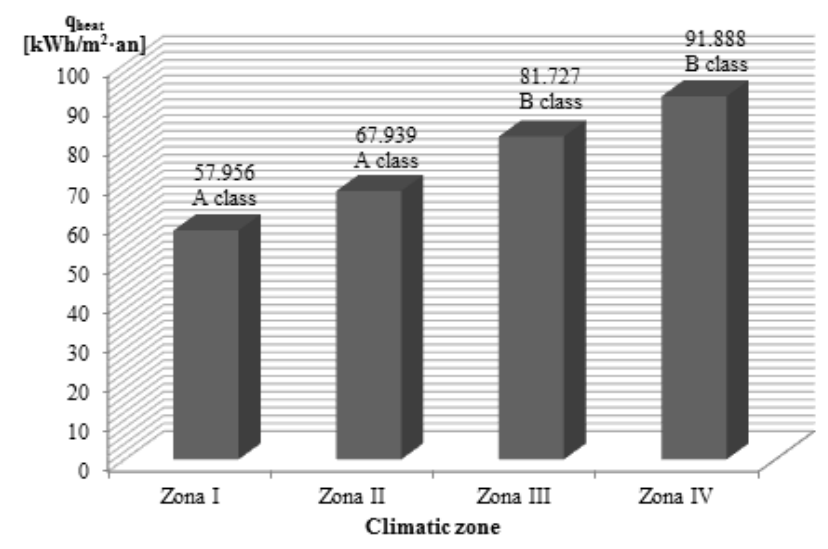

Figure 12. Heating index for the $\mathrm{GF}+6 \mathrm{~F}$ building

The figures emphasize the importance of the building location in one of the four climatic zones, on the energy performance of the building. The climatic conditions given by the temperature difference between interior and exterior, the heating degree days during a year and the intensity of the solar radiation has a significant influence on the energy class of a building (figures $13,14,15)$.

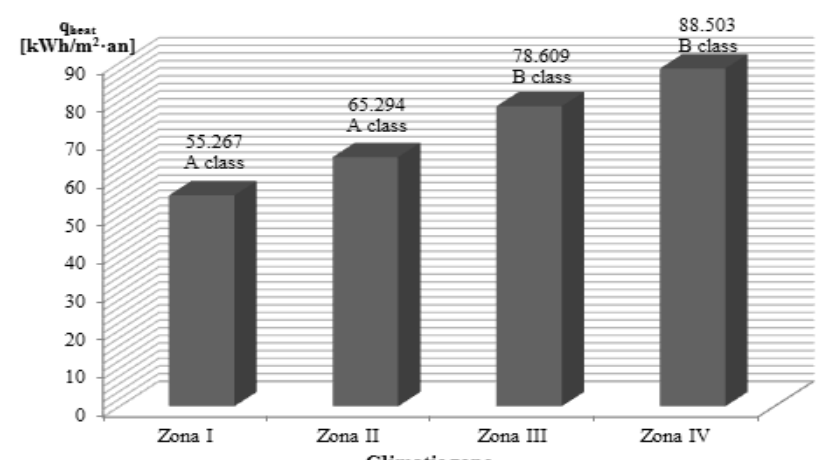

Figure 13. Heating index for the GF+10F building

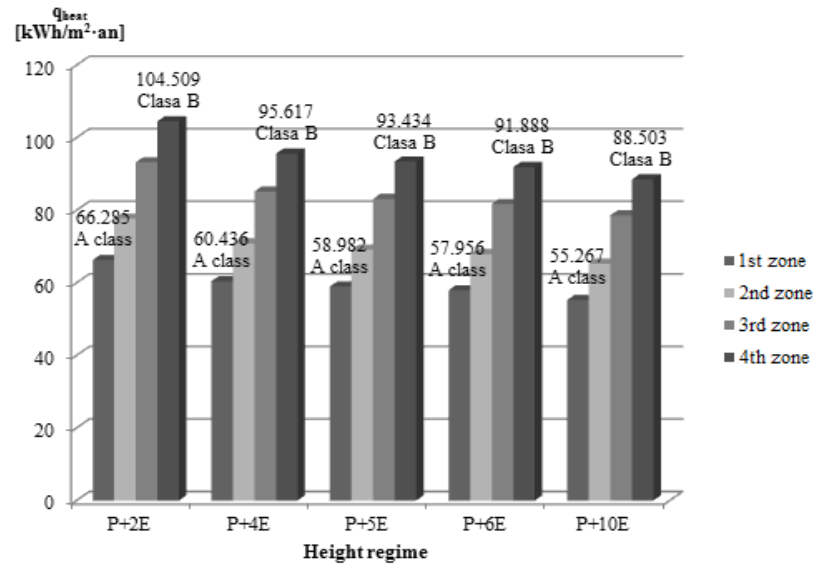

Figure 14. Heating index based on the building height 


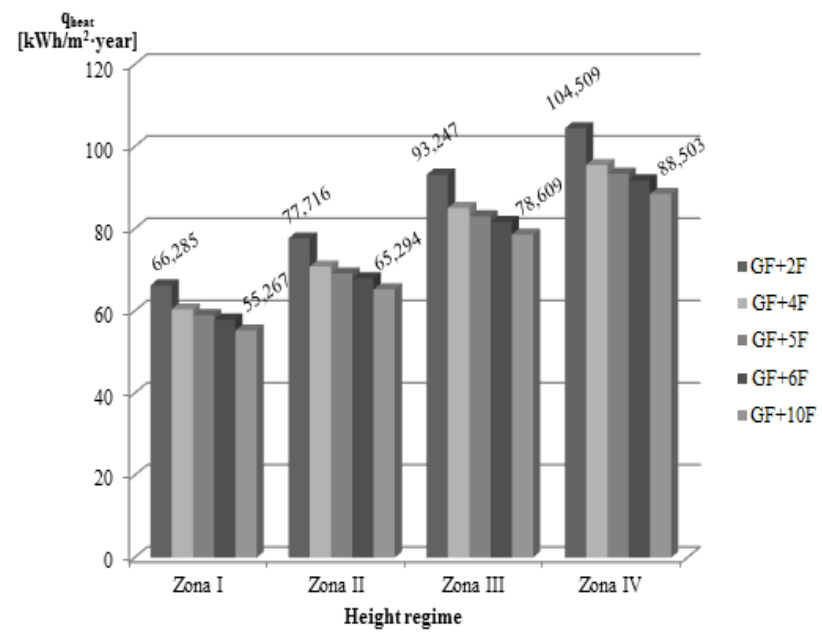

Figure 15. Heating index based on the climatic zone

\section{CONCLUSION}

The first conclusion of the above study is that the energy performance of a building can be optimised by a proper thermal rehabilitation activity on the existing building, as it can be seen on the summarised values shown in figure 4 .

The second part of the study indicated that the annual energy demand and the energy class of the building are directly influenced by the height regime of the building and the climatic zones were the building is placed. For the same shape and orientation of a building, the energy performance increases if the height regime of the building increases. The result for the building placed in the four climatic zones from Romania indicates the difference in the energy behaviour of the building, the energy consumptions having a tendency of increasing its consumptions from the first (i.e. the $1^{\text {st }}$ ) to the last climatic zone (i.e. the $4^{\text {th }}$ ).

The aim of this work is to provide building researchers and practitioners with a better understanding of the way climatic zones and various geometric characteristics of a building can influence the energy performance and thus the energy class of the building.

\section{ACKNOWLEDGEMENTS}

Funded by the European Social Fund Program POSDRU, DMI 1.5, ID 137516-PARTING.

\section{REFERENCE}

European Parliament and Council of 19 May 2010, 2010, Directive 2010/31/EU on the energy performance of buildings (recast).

Strategia Naţională pentru Dezvoltare Durabilă a României Orizonturi 2013-2020-2030 (National strategy for sustainable development of Romania, Horizons), 2008. Romanian Government, Environment and Sustainable Development
Minister, United Nations Programme for Development, National Centre for Sustainable Development , Bucharest, Romania.

C107:2010 (2005). Normativ privind calcul termotehnic al elementelor de constructive ale cladirilor (Romanian norm for the termotechnical calculation of the construction components of buildings).

Calitatea mediului interior si eficienta energetică a cladirilor (The quality of the interior environment and the energy efficiency of buildings), http://www.ecomagazin.ro/calitateamediului-interior-si-eficienta-energetica-a-cladirilor/ (view at 8.03.2015).

Mc0001-1-2-3, 2006. Metodologia de calcul al performanței energetice a clădirilor (The methodology for the energy performance calculation of a building.).

2513 Order from 22.11.2010. Modificarea Reglementării tehnice „Normativ privind calculul termotehnic al elementelor de construcţie ale clădirilor", indicativ C 107:2005 (Modification of the technical regulation „Norm for the termotechnical calculation of the construction components of buildings indicative C107:2005).

SR 1907/2- Instalaţii de încălzire- Necesarul de căldură de calcul. Temperaturi interioare convenţionale de calcul (Heating installations. Design conventional indoor temperatures).

Annex of the 1590 Order from 24.08.2012. Modification and supplement at the $\mathrm{C} 107$ volume 3 , Catalog cu punţi termice specifice clădirilor (Catalogue with specific thermal bridges for buildings).

Pacheco, R., Ordóñez, J., Martínez, G., 2012. Energy efficient design of building: A review, Renewable and Sustainable Energy Reviews, 16 (6), pp. 3559-3573.

Ourghi, R., Al-Anzi, A., Krarti, M., 2007. A simplified analysis method to predict the impact of shape on annual energy use for office buildings. Energy Conversion and Management, 48 (1), pp. 300-305.

AlAnzi, A., Seo, D., Krarti, M., 2009. Impact of building shape on thermal performance of office buildings in Kuwait. Energy Conversion and Management, 50 (3), pp. 822-828.

Granadeiro, V., Correia, J. R., Leal, V. M.S., Duarte, J.P., 2013. Envelope-related energy demand: A design indicator of energy performance for residential buildings in early design stages. Energy and Buildings, 61, pp. 215-223.

Sozer, H., 2010. Improving energy efficiency through the design of the building envelope, Building and Environment, 45 (12), pp. 2581-2593.

Depecker, P., Menezo, C., Virgone, J., Lepers, S., 2001. Design of buildings shape and energetic consumption. Building and Environment, 36 (5), pp. 627-635.

Moga, L., Moga I., 2009. The energetic performance of the building envelope elements- intersection of linear thermal bridges. The Fifth International Workshop on Energy and 
Environment of Residential Buildings and The Third International Conference on Built Environment and Public Health EERB-BEPH, Guilin, Guangzhou, China.

Moga, L., Moga I., 2011. Thermal rehabilitation of buildings with high thermal inertia. $12^{\text {th }}$ International Conference on Indoor Air Quality and Climate 2011, Volume 3, Texas University, Austin, Texas, USA.

Florides, G. A., Tassou, S. A., Kalogirou, S. A., Wrobel, L. C., 2002. Measures used to lower building energy consumption and their cost effectiveness. Applied Energy, 73 (3-4), pp. 299-328.

Asadi, E., Silva, M.G., Antunes, C.H., Dias, L., 2012. Multiobjective optimization for building retrofit strategies: a model and an application, Energy and Buildings, 41, pp. 81-87.

Suresh, B.S., Madala, S., Boehm, R.F., 2011. Passive building energy savings: A review of building envelope components. Renewable and Sustainable Energy Reviews, 15 (8), pp. 36173631 .

Dakwale, V.A., Ralegaonkar, R. V., Mandavgane, S., 2011. Improving environmental performance of building through increased energy efficiency: A review. Sustainable Cities and Society, 1 (4), pp 211-218. 